\title{
Increased Auditory Cortex Neural Response Amplitude in Adults with Chronic Unilateral Conductive Hearing Impairment
}

Lauren V. Parry ${ }^{1}$, Michael R.D. Maslin ${ }^{1}$, Roland Schaette ${ }^{2}$, David R Moore ${ }^{1,3,4}$ and Kevin J. Munro $^{1,4}$

${ }^{1}$ Manchester Centre for Audiology and Deafness, School of Health Sciences, University of Manchester, Oxford Road, Manchester, M13 9PL, United Kingdom.

${ }^{2}$ Ear Institute, University College London, London, WC1X 8EE, United Kingdom

${ }^{3}$ Cincinnati Children's Hospital Medical Centre and Department of Otolatyngology, University of Cincinnati College of Medicine, Cincinnati, Ohio, United States of America

${ }^{4}$ NIHR Manchester Biomedical Research Centre, Central Manchester University Hospitals NHS Foundation Trust, Manchester Academic Health Science Centre, Manchester, M13 9WL, United Kingdom

Corresponding Author:

Lauren Parry

Paediatric Audiology, Children's Outpatients

Leighton Hospital

Crewe

CW1 4QJ

Tel.: 01270275802

Email: lauren.parry@mcht.nhs.uk 


\begin{abstract}
Animal studies have demonstrated that unilateral hearing loss can induce changes in neural response amplitude of the mature central auditory system (CAS). However, there is limited physiological evidence of these neural gain changes in the auditory cortex of human adults. The present study investigated the impact of chronic, unilateral conductive hearing impairment on cortical auditory evoked potentials (CAEPs) recorded from 15 adults (21-65 years old) in response to a $1 \mathrm{kHz}$ tone ( $80 \mathrm{~ms}$ duration) presented to the impaired ear via a bone conduction transducer. The amplitude and latency of the main CAEP components were compared to those obtained from normal hearing age-matched control participants. Both P1$\mathrm{N} 1$ and N1-P2 amplitudes were significantly larger in the hearing impaired relative to the control participants. Differences between groups in the mean latencies of P1, N1, and P2 were not statistically significant. These results are the first to provide direct evidence of increased neural response amplitude in the adult human auditory cortex in the presence of unilateral conductive hearing loss. Importantly, the study shows that central gain changes are a direct result of deprivation of sound rather than cochlear or neural pathology.
\end{abstract}

Keywords: auditory deprivation, plasticity, cortical auditory evoked potential, adult

Abbreviations: (CAS) central auditory system, (ART) auditory reflex threshold, (ABR) auditory brainstem response, (CAEP) cortical auditory evoked potential 


\section{Introduction}

To understand the functional consequences of hearing loss, we not only need to understand its effects on processing at the level of the cochlea and auditory nerve, but also how it affects the central auditory system (CAS). Since hearing loss reduces the overall sound-evoked activity of the auditory nerve and thus the input signal to the brain, one would expect to find a subsequent reduction in neural activity within the CAS. However, increases in spontaneous and stimulus-evoked neural firing have been observed in the auditory system of adult animals following a cochlear lesion (for review see Roberts et al., 2010; Schaette et al., 2014; Brotherton et al., 2015). It is thought that these changes in neural activity may be due to homeostatic plasticity, a mechanism thought to regulate neural excitability and synaptic efficiency in order to stabilize cortical activity (Turrigiano, 1999). Increases in spontaneous neuronal activity were found in the dorsal cochlear nucleus (Dehmel et al., 2012; Kaltenbach et al., 2002; Manzoor et al., 2013), the inferior colliculus (Manzoor et al., 2013; Mulders and Robertson, 2009; Hesse et al., 2016) and the auditory cortex (Ahlf et al., 2012; Norena and Eggermont, 2003) following cochlear trauma. Similarly, studies investigating stimulus-evoked activity have found an increase in neural responsiveness within subcortical pathways (Cai et al., 2008; Dehmel et al., 2012; Hickox and Liberman, 2014) and the auditory cortex (Chambers et al., 2016). These animal studies have all involved introduction of a cochlear lesion either through acoustic trauma or the administration of ototoxic drugs. Both of these interventions typically cause loss of cochlear hair cells (Dallos and Harris, 1978; Kaltenbach et al., 2002; Chen and Fechter, 2003) and degeneration of auditory nerve fibres (Webster and Webster, 1981; Kujawa and Liberman, 2009; Chambers et al., 2016). Therefore, it is difficult to disentangle whether the observed changes in neural activity in the auditory brain are provoked by sensory deprivation or sensorineural pathology.

An alternative model to assess changes in central auditory processing is to investigate the effects of a conductive hearing impairment. Conductive impairments typically result in a reduction of sound energy reaching the cochlea, with the cochlea and the CAS remaining largely intact (Moore et al., 1989). As such, this model of sensory deprivation allows us to remove sensorineural damage as a confounding factor. A number of studies have used conductive hearing impairments to investigate neural gain changes. Decker and Howe (1981) assessed the ipsilateral acoustic reflex threshold (ART) following unilateral earplugging to investigate central gain changes in adult humans. Following 30 hours of plugging, a nonsignificant reduction in ART of the deprived ear was recorded following unplugging. More recent studies have revisited the ART in adults after longer periods of auditory deprivation. A significant reduction in ART of the deprived ear has been recorded after 7 days of unilateral 
earplugging (Munro and Blount, 2009; Maslin et al., 2013; Munro et al., 2014). These studies are indirect evidence of a change in neuronal processing in the CAS, and the results are consistent with an increase in neuronal response gain in subcortical auditory pathways after sensory deprivation.

Animal studies have shown that conductive hearing impairment induces reversible synaptic changes in auditory subcortical pathways. Whiting et al. (2009) used earplugging to induce a unilateral conductive hearing impairment in normal-hearing rats. They reported altered expression of glycine and glutamate receptor subunits within the ventral and dorsal cochlear nucleus after 24 hours of earplug use, an effect that was fully reversible following removal of the earplug. Furthermore, Tucci et al., (1999) found reduced uptake of 2Deoxyglucose in brainstem auditory nuclei in the auditory pathway of an ear with conductive hearing impairment, indicative of increased neural firing in the subcortical pathways of the impaired ear. It would be expected that any change in subcortical pathways would influence stimulus-evoked activity in the auditory cortex; however, this was not evident on functional magnetic resonance imaging (fMRI) of adult humans following a period of unilateral earplugging, despite evidence of subcortical changes on acoustic reflex threshold (ART) testing (Maslin et al., 2013).

Stimulus-evoked neural activity can be assessed directly in humans by measuring auditory evoked potentials. Decker and Howe (1981) used auditory brainstem responses (ABR) to measure subcortical activity on stimulation of a previously deprived ear after 30 hours of earplugging, recording a non-significant trend for reduced latency of wave I. Unlike ART measures, this finding was not supported in a study of long-term unilateral deprivation (Ferguson et al., 1998).

To date, no animal or human studies have reported a change in stimulus-evoked activity in the mature auditory cortex on stimulation of an ear with an intact cochlea that has been subjected to auditory deprivation. The aim of the present study was to investigate cortical auditory evoked potentials (CAEPs) in adults with late-onset, unilateral conductive hearing impairment on stimulation of the impaired ear. Chronic impairments were studied in order to ensure sufficient length of sensory deprivation. It was hypothesised that stimulation of the impaired ear would result in greater neural activity compared to normal-hearing controls, evidenced by higher amplitudes and shorter latencies of the CAEP components.

\section{Methods}

\subsection{Participants}


This was a case-control study with two groups of 15 participants. The aetiology of hearing impairment for the experimental group are summarised in Table 1. Pure tone audiogram thresholds are detailed in Table 2. The experimental group was matched with controls by age, sex and hearing in the intact ear. We were unable to use the normal hearing ear of the unilaterally impaired participants as a control, as the high level of masking required to mask the impaired 'non-test' ear would risk crossing to the normal hearing test ear and reduce validity of any findings. Ethics approval was obtained from Camberwell St Giles REC (reference: $14 / \mathrm{LO} / 1223$ ).

Insert Table 1 here.

Insert Table 2 here.

\subsection{Stimuli and Procedures}

A Bio-logic NavPro system was used to record the CAEPs. The stimulus used was a 1 $\mathrm{kHz}$ tone (80 ms duration) with a repetition rate of $1.1 / \mathrm{s}$. A $1 \mathrm{kHz}$ stimulus was used as lower frequency tonal stimuli produce larger CAEP amplitudes than higher frequency stimuli (Jacobson et al., 1992). A $1 \mathrm{kHz}$ CAEP is therefore likely to be maximally sensitive to neuroplasticity. A high pass filter of $1 \mathrm{~Hz}$ and a low pass filter of $15 \mathrm{~Hz}$ were used. The artefact rejection level was $20 \mu \mathrm{V}$. A total of 500 accepted sweeps was recorded from each participant. The stimulus was presented to the test ear mastoid via a bone conduction transducer, at a comfortable supra-threshold level of $20 \mathrm{~dB}$ above the bone conduction threshold determined by Pure Tone Audiogram (PTA).

A bone conduction transducer was used in order to prevent introduction of error by correcting for the conductive element of hearing impairment when providing a stimulus via air conduction. Masking was required to isolate the test ear and ensure there was no crosshearing of stimulus. The CAEP is generated at a level above where binaural interaction occurs. It is thought that contralateral broadband masking alters peak amplitudes but has no overall effect on peak to trough amplitudes and peak latencies of the CAEP (Salo et al., 2003). Continuous pink noise masking was provided to the unaffected ear via a supra-aural headphone. Broadband masking is thought to be equally effective to narrow band noise (although perceived as louder), and was chosen in this case due to availability (Tate, 2013). The masking level was $30 \mathrm{~dB}$ above the stimulus level. This level was chosen as it was 
sufficient to provide effective masking of the non-test ear with a low risk of cross-masking (Munro and Agnew, 1999).

Participants were seated in a reclining chair in a sound-attenuating booth. Participants were seated in a reclining chair in a sound-attenuating booth. The booth complied with British Standards (British Standards Institution, 2010) for maximum permitted ambient noise levels for audiometry and therefore the findings are not likely to have been influenced by ambient noise. No active responses were required from the participants but general alertness was maintained by watching a movie with subtitles and the sound disabled. Three gold-plated surface electrodes were used; the negative was placed on the mastoid of the test ear, the positive at $\mathrm{Cz}$ and a common electrode on the mastoid of the non-test ear. The measurement lasted approximately 10 minutes.

Peaks and troughs were identified as the first three waves of the averaged trace where P1 was the most positive peak occurring closest to $50 \mathrm{~ms}$, N1 was the most negative occurring closest to $100 \mathrm{~ms}$ and P2 was the most positive peak closest to $180 \mathrm{~ms}$. Latency was measured as the absolute latency at the peak of the wave. Peak-to-trough amplitude was measured as the difference in amplitude $(\mu \mathrm{V})$ between peaks (P1-N1, N1-P2). Peaks were determined by an experienced clinical scientist who was blinded to test ear and group, and checked by an independent second tester.

\subsection{Statistical Analysis}

The main analysis involved a comparison of difference in grand average means between groups for absolute latencies and peak-to-trough amplitudes. The data were normally distributed so the analysis consisted primarily of independent samples $t$-tests. Because there were multiple pair comparisons ( 2 for amplitude and 3 for latency), the more conservative significance level of 0.01 was used. Residual noise was calculated with the \pm reference method (Schimmel, 1967).

\section{Results}

\subsection{Audiometry}

Figure 1 shows the mean pure tone audiogram for hearing impaired participants and control group. Hearing impairment generally produced a flat conductive hearing loss from 0.25 to $8 \mathrm{kHz}$. Table 1 shows $1 \mathrm{kHz}$ audiometric data and median values for the hearing 
impaired and control group. Pure tone average $(0.5-4 \mathrm{kHz}$ mean) was $\leq 20 \mathrm{~dB}$ HL for the normal ear of hearing impaired participants and for both ears of control participants. Mean air-bone gap at $1 \mathrm{kHz}$ for the hearing-impaired ears was $37 \pm 2.22 \mathrm{~dB} \mathrm{HL}$ (range: 25-55 dB HL). Interestingly, there does appear to be a 'Carhart's notch' at $2 \mathrm{kHz}$ for the hearing impaired group. 2 participants had been diagnosed with otosclerosis which may have contributed partly to this finding. Although a Carhart's notch is considered to be a characteristic finding in those with otosclerosis, it has been documented that other middle ear disorders may also present with a $2 \mathrm{kHz}$ notch on bone conduction testing, for example otitis media (Kumar et al., 2003). Therefore, it was anticipated that a $2 \mathrm{kHz}$ notch in bone conduction threshold might appear for the hearing impaired group.

\section{Insert Figure 1 here.}

Mean bone conduction thresholds at $1 \mathrm{kHz}$ for the hearing-impaired ears did not differ significantly from either bone conduction $(\mathrm{p}=0.66$, independent samples t-test) or air conduction $(\mathrm{p}=0.48$, independent samples t-test) thresholds of the control group at $1 \mathrm{kHz}$, demonstrating normal inner ear sensitivity of the hearing-impaired group despite the conductive loss.

\subsection{Waveform comparison}

Grand average waveforms for each group are displayed in Figure 2. No difference in peak values was found when comparing manual measurement to measurement using an automated peak detection algorithm. Figure 3 shows grand average of residual noise for each group. There was no significant difference between groups in RMS signal-to-noise across the waveform $(p=0.13)$.

Insert Figure 2 here.

\subsection{CAEP amplitudes}

Figure 4 shows boxplots for the CAEP peak-to-trough amplitude data, obtained for responses to $1 \mathrm{kHz}$ tones delivered via bone conduction at $20 \mathrm{~dB}$ SL. The mean peak-to-trough amplitudes of P1-N1 and N1-P2 were significantly greater in response to stimulation of the impaired ears than the control ears (see Table 3). 
Insert Figure 4 here.

Insert Table 3 here.

\subsection{CAEP latencies}

Figure 5 shows boxplots for the absolute latencies of the CAEPs. Latencies of all three peaks were shorter for the impaired ears relative to the controls, but the mean difference reached $\mathrm{p}<0.05$ only for $\mathrm{P} 1(\mathrm{p}=0.03$, see Table 3$)$. This finding cannot be considered significant in light of the conservative significance level of $p<0.01$ to account for multiple comparisons.

Insert Figure 5 here.

Insert Table 4 here.

\section{Discussion}

This study investigated the impact of chronic, unilateral conductive hearing impairment on the neural response amplitude of the auditory cortex. CAEPs recorded from bone stimulation of the deprived ear of adults with chronic, unilateral conductive hearing impairment were compared to those of a normal hearing control group provided with equivalent stimulation. The hearing-impaired group had significantly larger mean P1-N1-P2 amplitudes than the control group. Shorter mean latencies of these waves were also observed. These findings support the hypothesis that unilateral auditory deprivation causes an increase in neural responsiveness of the CAS.

The difference in CAEP amplitude between the two groups cannot be explained by differences in stimulus or masker levels. Stimulation was provided to all participants via a bone conduction transducer at $20 \mathrm{~dB}$ SL, together with contralateral masking at $30 \mathrm{~dB}$ above stimulus level. Peak-to-trough amplitudes for the control participants were comparable to unpublished normative data from our lab. Based on our normative data, we estimate that a difference in stimulus level of at least $20 \mathrm{~dB}$ for P1-N1, and at least $40 \mathrm{~dB}$ for N1-P2, would be required to cause CAEP amplitude differences of the same magnitude as we observed between study and control groups. As there was no significant difference in stimulus level between groups in our study, the larger amplitudes measured in the hearing-impaired group 
cannot be attributed a higher stimulus level. There was a small, non-significant difference between groups in the $1 \mathrm{kHz}$ air conduction threshold of the non-test ear. As the same masking paradigm was used for all participants, this finding cannot be attributed to crossmasking (Munro and Agnew, 1999).

The underlying reason for the change in neural response observed may be a neural adaptation mechanism known as 'homeostatic plasticity' (Turrigano, 1999). It is thought that homeostatic mechanisms regulate neuronal excitability and synaptic efficiency in order to stabilize cortical activity. This is achieved by scaling the strength of excitatory and inhibitory synapses, and by modifying intrinsic neuronal excitability, to keep the firing rates within a functional boundary. Thus, homeostatic plasticity acts as a compensatory gain regulation mechanism that might also be involved in adjustment to persistent changes in sensory input. This would have the effect of increasing amplitudes and reducing latencies of auditory evoked activity of the deprived ear, as seen in the present study. This may be the same type of mechanism proposed in animal studies to regulate experience-dependent gain control (also called stimulus-specific adaptation) in the auditory midbrain and thalamus on faster time scales (Dean et al., 2005; Malmierca et al., 2015). Interestingly, that mechanism has recently been found to be influenced by cortical activity over longer time scales, a phenomenon termed meta-adaptation (Robinson et al., 2016).

An alternative explanation may lie in binaural interaction. Long-latency binaural interaction has been observed from $90 \mathrm{~ms}$, covering the duration of the $\mathrm{N} 1$ and $\mathrm{P} 2$ components of the CAEP. These interactions are all inhibitory in form (McPherson and Starr, 1993). It is known that contralateral masking has an inhibitory effect, reducing the amplitude of CAEP components (Connelly, 1993). A reduction in binaural interaction would reduce the inhibitory effect of contralateral masking and result in increased amplitude of P1-N1 and N1$\mathrm{P} 2$, as seen in the present study. Other data have shown that binaural interaction, as measured by binaural unmasking, is reduced in cases of chronic unilateral hearing loss (Ferguson et al., 1998). Measures of the auditory brainstem response showed prolonged latency of wave V, suggesting a midbrain origin for the effect. However, these data are inconsistent with the general trend for reduced peak latencies found here. It is therefore unlikely that the findings of the present study can be attributed solely to plasticity of sub-cortical binaural interaction.

One limitation of the present study was the inability to obtain baseline data before the conductive hearing loss occurred. As a result, any correlation between the change in CAEP and other variables could not be determined. Longitudinal studies could identify a correlation between CAEP amplitude and length of deprivation period or age at onset, which would help 
our understanding of neural mechanisms for adaptation. This is one benefit of mimicking a conductive hearing loss with earplugging. However, it would not be possible to provide longterm deprivation with this method, and a study involving earplugging for one week produced only minimal behavioural adaptation (McPartland et al., 1997).

Another limitation of the study is that testing was limited to one frequency, one stimulus level and, in particular, one recording channel. This testing paradigm does not allow for analysis of the distribution of response across the cephalic surface and therefore limits interpretation of findings. Therefore, future studies may wish to go beyond replication to explore multi-channel recording with multiple stimuli.

To date, no other human study has directly measured a change in neural activity of the mature auditory cortex on stimulation of an ear that has been deprived of sensory stimulation. There is, however, indirect evidence of adaptation at a subcortical level. A number of studies have found a reduction in ART following a period of unilateral earplugging (Decker and Howe, 1981; Munro and Blount, 2009; Maslin et al., 2013; Munro et al., 2014). This suggests that short-term, partial, auditory deprivation is sufficient to induce a change in the auditory pathways at a subcortical level, specifically a reduction in threshold of neuronal excitability. The present study supports this finding, evidencing a change in neural activity at a cortical level.

This study is the first to demonstrate a change in cortical response amplitude in adults with unilateral conductive hearing impairment. There are a number of methodological differences between the present and previous studies which may have led to the contrast in findings. Firstly, it is known that cortical adaptations can occur over at least a 12-month period (Jones, 2000). As such, a significantly shorter period of deprivation of 7 days (McPartland et al., 1997; Maslin et al., 2013) may be insufficient to induce cortical adaptations. Secondly, Maslin et al. (2013) indirectly recorded neural activity by measuring changes in blood oxygen level with fMRI; a method which may not detect small, intrinsic neuronal changes (Hall and Wild, 2012). This method has the additional challenge of loud ambient noise from the scanner, which may have partly provided a masking effect, even with the use of sparse sampling test paradigms. Thirdly, the stimulus intensity used by Maslin et al. (2013) was at $90 \mathrm{~dB}$ SPL, significantly higher than the level used in the present study. The high intensity of stimulus may have saturated neuronal activity and obscured differences between groups.

Animal studies have shown that a deprivation of input to the central auditory system through cochlear damage results in an increased spontaneous neural firing at all levels of the 
CAS (dorsal cochlear nucleus: Dehmel et al., 2012; Kaltenbach et al., 2002; Manzoor et al., 2013; inferior colliculus: Manzoor et al., 2013; Jastreboff and Sasakia, 1986; auditory cortex Ahlf et al., 2012; Norena and Eggermont, 2003). Furthermore, animal studies have demonstrated changes in stimulus-evoked neural responsiveness at a subcortical level following cochlear damage (Cai et al., 2008; Dehmel et al., 2012). It is thought that the mechanisms responsible for this change reside within the dorsal cochlear nucleus, and these changes are then relayed to the midbrain and the auditory cortex (Manzoor et al., 2013). Changes in subcortical activity may be recorded within the auditory cortex, possibly with amplification or some other modulation. These subsequent changes in cortical activity have been demonstrated in mice following near-complete cochlear denervation (Chambers et al., 2016). Although similar subcortical changes have been observed in animals (Whiting et al., 2009) and humans (Maslin et al., 2013) following late-onset conductive hearing impairment alone, no other study has robustly measured these changes in the mature, ipsilateral auditory cortex in the absence of cochlear damage.

\section{Conclusion}

The present study is the first to demonstrate significant changes in activity within the cortex of adult humans with unilateral conductive hearing impairment. The finding supports other observations of neural gain changes in the CAS occurring in response to changes in auditory experience rather than cochlear or neural pathology. 


\section{Funding}

KJM and DRM were supported by the NIHR Manchester Biomedical Research Centre. The views expressed are those of the author(s) and not necessarily those of the NHS, the NIHR or the Department of Health.

\section{Author Declaration}

The authors declare that there are no conflicts of interest.

\section{Acknowledgement}

The authors would like to thank Christopher Brockbank and his team in Audiology at Lancashire Teaching Hospitals NHS Trust for their help with data collection. 


\section{References}

Ahlf, S., Tziridis, K., Korn, S., Strohmeyer, I., Schulze, H., 2012. Predisposition for and prevention of subjective tinnitus development. PLoS ONE. 7:e44519.

British Standards Institution, 2010. Acoustics. Audiometric test methods. Pure-tone air and bone conduction audiometry. London, England: BSI.

Brotherton, H., Plack, C.J., Maslin, M., Schaette, R., Munro, K.J., 2015. Pump up the volume: could excessive neural gain explain tinnitus and hyperacusis? Audiol Neurootol. 20, 273-282.

Cai, S., Ma, W.L.D., Young, E.D., 2008. Encoding intensity in ventral cochlear nucleus following acoustic trauma: implications for loudness recruitment. J Assoc Res Otolaaryngol. 10, 5-22.

Chambers, A.R., Resnik, J., Yuan, Y., Whitton, J.P., Edge, A.S., Liberman, M.C., Polley, D.B., 2016. Central gain restores auditory processing following near-complete cochlear denervation. Neuron. 89, 867-879.

Chen, G.D., Fechter, L.D., 2003. The relationship between noise-induced hearing loss and hair cell loss in rats. Hear Res. 177, 81-90.

Connelly, J.F., 1993. The influence of stimulus intensity, contralateral masking and handedness on the temporal $\mathrm{N} 1$ and the $\mathrm{T}$ complex components of the auditory $\mathrm{N} 1$ wave. Electroencephalogr Clin Neurophysiol. 86, 58-68.

Dallos, P., Harris, D., 1978. Properties of auditory nerve responses in absence of outer hair cells. J Neurophysiol. 41, 365-383.

Dean, I., Harper, N.S., McAlpine, D., 2005. Neural population coding of sound level adapts to stimulus statistics. Nat Neurosci. 8, 1684-1689.

Decker, T.N., Howe, S.W., 1981. Short term auditory deprivation: effect on brainstem electrical response. Hear Res. 4, 251-263.

Dehmel, S., Pradhan, S., Koehler, S., Bledsoe, S., Shore, S., 2012. Noise overexposure alters long-term somatosensory-auditory processing in the dorsal cochlear nucleus - possible basis for tinnitus related hyperactivity? J Neurosci. 32, 1660-1671.

Ferguson, M.O., Cook, R.D., Hall, J.W., 1998. Chronic conductive hearing loss in adults: effects on the auditory brainstem response and masking-level difference. Arch Otolaryngol Head Neck Surg. 124 (6), 678-685. 
Hall, D.A., Wild, D.C., 2012. Fundamental principles underlying MRI and functional MRI. In: Tremblay, K.B.R. (ed.) Translational perspectives in auditory neuroscience: hearing across the lifespan - assessment and disorders. San Diego: Plural Publishing Inc.

Hesse, L.L., Bakay, W.H., Anderson, L., Ong, H-C., Ashmore, J., McAlpine, D., Linden, J.F., Schaette R., 2016. Non-Monotonic Relation between Noise Exposure Severity and Neuronal Hyperactivity in the Auditory Midbrain. Front Neurol. 25 (7), 133.

Hickox, A.E., Lieberman, M.C., 2014. Is noise-induced cochlear neuropathy key to the generation of hyperacusis or tinnitus? J Neurophysiol. 111, 552-564.

Jacobson, G.P., 1992. The effects of stimulus frequency and recording site on the amplitude and latency of multichannel cortical auditory evoked potential (CAEP) component N1. Ear Hear. 13, 300-306.

Jastreboff, P.J., Sasaki, C.T., 1986. Salicylate-induced changes in spontaneous activity of single units in the inferior colliculus of the guinea pig. J Acoust Soc Am. 80, 13841391.

Jones, E., 2000. Cortical and subcortical contributions to activity-dependent plasticity in primate somatosensory cortex. Annu Rev Neurosci. 23, 1-37.

Kaltenbach, J.A., Rachel, J.D., Mathog, T.A., Zhang, J., Falzarano, P.R., Lewandowski, M., 2002. Cisplatin-induced hyperactivity in the dorsal cochlear nucleus and its relation to outer hair cell loss: relevance to tinnitus. J Neurophysiol. 88, 699-714.

Kujawa, S.G., Liberman, M.C., 2009. Adding insult to injury: cochlear nerve degeneration after 'temporary' noise-induced hearing loss. J Neurosci. 29, 14077-14085.

Kumar, M., Maheshwar, A., Mahendran, S., Oluwasamni, A., Clayton, M.I., 2003. Could the presence of a Carhart notch predict the presence of glue at myringotomy? Clin Otolaryngol. 28(3), 183-186.

Malmierca, M.S., Anderson, L.A., Antunes, F., 2015. The cortical modulation of stimulusspecific adaptation in the auditory midbrain and thalamus: a potential neuronal correlate for predictive coding. Front Syst Neurosci. 9(19), 1-14.

Manzoor, N.F., Gao, Y., Licari, F., Kaltenbach, J.A., 2013. Comparison and contrast of noiseinduced hyperactivity in the dorsal cochlear nucleus and inferior colliculus. Hear Res. 295, 114-123. 
Maslin, M., Munro, K., Lim, V., Purdy, S., Hall, D., 2013. Investigation of cortical and subcortical plasticity following short-term unilateral auditory deprivation in normal hearing adults. Neuroreport. 24, 287-291.

McPartland, J.L., Culling, J.F., Moore, D.R., 1997. Changes in lateralization and loudness judgements during one week of unilateral ear plugging. Hear Res, 113, 165-172.

Mcpherson, D.L., Starr, A., 1993. Binaural interaction in auditory evoked potentials: brainstem, middle- and long-latency components. Hear Res. 66, 91-98.

Moore, B.J., 2012. An introduction to the psychology of hearing. England, Cambridge: Emerald Group Publishing Ltd. $6^{\text {th }}$ Ed.

Moore, D.R., Hutchings, M.E., King, A.J., Kowalchuk, N.E., 1989. Auditory brainstem of the ferret some effects of rearing with a unilateral ear plug on the cochlea, cochlear nucleus, and projections to the inferior colliculus. J Neurosci. 9, 1213-1222.

Morita, T., Naito, Y., Nagamine, T., Fujiki, N., Shibasaki, H., Ito, J., 2003. Enhanced activation of the auditory cortex in patients with inner-ear hearing impairment: a magnetoencephalographic study. Clin Neurophys. 114, 851-859.

Mulders, W.H., Robertson, D., 2009. Hyperactivity in the auditory midbrain after acoustic trauma: dependence on cochlear activity. Neuroscience. 164, 733-746.

Munro, K., Agnew, N., 1999. A comparison of inter-aural attenuation with the Etymotic ER3A insert earphone and the Telephonics TDH-39 supra-aural earphone. Br J Audiol. 33, 259-262.

Munro, K., Blount, J., 2009. Adaptive plasticity in brainstem of adult listeners following earplug-induced deprivation. J Acoust Soc Am. 126, 568-571.

Munro, K.J., Turtle, C., Schaette, R., 2014. Sub-cortical plasticity and modified loudness following short-term unilateral deprivation: evidence of multiple neural gain mechanisms within the auditory system. J Acoust Soc Am. 135, 315-322.

Norena, A.J., Eggermont, J.J., 2003. Changes in spontaneous neural activity immediately after an acoustic trauma: implications for neural correlates of tinnitus. Hear Res. 183, 137-153.

Roberts, L.E., Eggermont, J.J., Caspary, D.M., Shore, S.E., Melcher, J.R., Kaltenbach, J.A., 2010. Ringing ears: the neuroscience of tinnitus. J Neurosci. 30, 14972-14979.

Robinson, B.L., Harper, N.S., McAlpine, D., 2016. Meta-adaptation in the auditory midbrain under cortical influence. Nat Commun. 24, 13442. 
Salo, S.K., Lang, A.H., Salmivalli, A.J., Johansson, R.K., Peltola, M.S., 2003. Contralateral white noise masking affects auditory N1 and P2 waves differently. J Psychophysiol. 17, 189-194.

Schaette, R., 2014. Tinnitus in men, mice (as well as other rodents), and machines. Hear Res. $311,63-71$.

Schaette, R., Turtle, C., Munro, K., 2012. Reversible induction of phantom auditory sensations through simulated unilateral hearing loss. PloS One. 7, e35238.

Schimmel, H., 1967. The ( \pm ) Reference: accuracy of estimated mean components in average response studies science. 157 (3784), 92-94.

Tate, M., 2013. Principles of hearing aid audiology. Springer: ISBN 978-1-4899-7152-4.

Tucci, D.L., Cant, N.B., Durham, D., 1999. Conductive hearing loss results in a decrease in central auditory system activity in the young gerbil. Laryngoscope. 109, 1359-1371.

Turrigiano, G., 1999. Homeostatic plasticity in neuronal networks: the more things change, the more they stay the same. Trends Neurosci. 22 (5), 221-227.

Webster, M., Webster., D.B., 1981. Spiral ganglion neuron loss following organ of corti loss: a quantitative study. Brain Res. 212, 17-30.

Whiting, B., Moiseff, A., Rubio, M.E., 2009. Cochlear nucleus neurons redistribute synaptic AMPA and glycine receptors in response to monaural conductive hearing loss. Neuroscience. 163, 1264-1276. 


\section{Tables}

Table 1. Participant demographics, aetiologies and pure tone audiogram data. Data for the control group are in brackets. Control participants were matched for age and sex. The choice of 'test ear' for the control group was determined by the impaired ear of the experimental group.

$1 \mathrm{kHz}$ threshold (dB HL)

\begin{tabular}{|c|c|c|c|c|c|c|c|}
\hline No. & Sex & $\begin{array}{l}\text { Age } \\
\text { (years) }\end{array}$ & Aetiology & $\begin{array}{l}\text { Duration of } \\
\text { impairment } \\
\text { (years) }\end{array}$ & $\begin{array}{l}\text { Impaired } \\
\text { ear }\end{array}$ & $\begin{array}{l}\text { Bone } \\
\text { conduction }\end{array}$ & Air conduction \\
\hline 1 & Female & $65[63]$ & Mastoidectomy & 6 & Left & $0[-5]$ & $35[0]$ \\
\hline 2 & Female & $21[27]$ & Perforation & 2 & Left & $10[5]$ & $40[0]$ \\
\hline 3 & Male & $51[48]$ & $\begin{array}{l}\text { Chronic supportive } \\
\text { otitis media }\end{array}$ & 10 & Left & $10[0]$ & $60[0]$ \\
\hline 4 & Male & $26[22]$ & Unknown & 10 & Left & $5[0]$ & $30[0]$ \\
\hline 5 & Female & $55[52]$ & Perforation & 21 & Left & $-5[10]$ & $35[15]$ \\
\hline 6 & Male & $60[55]$ & $\begin{array}{l}\text { Ossicular chain } \\
\text { discontinuity }\end{array}$ & 5 & Left & $10[-5]$ & $40[0]$ \\
\hline 7 & Male & $32[27]$ & Perforation & 10 & Left & $-10[10]$ & $30[10]$ \\
\hline 8 & Female & $21[24]$ & Perforation & 10 & Right & $5[5]$ & $40[-5]$ \\
\hline 9 & Female & $57[52]$ & Mastoidectomy & 7 & Right & $10[10]$ & $60[10]$ \\
\hline 10 & Male & $33[24]$ & Mastoidectomy & 9 & Right & $5[0]$ & $60[0]$ \\
\hline 11 & Male & $49[46]$ & $\begin{array}{l}\text { Ossicular chain } \\
\text { discontinuity }\end{array}$ & 1 & Right & $5[5]$ & $40[5]$ \\
\hline 12 & Female & $54[50]$ & Perforation & 20 & Right & $20[5]$ & $65[5]$ \\
\hline 13 & Male & $27[24]$ & Cholesteatoma & 1 & Right & $5[5]$ & $35[5]$ \\
\hline 14 & Male & $48[45]$ & $\begin{array}{l}\text { Eustachian tube } \\
\text { dysfunction }\end{array}$ & 1 & Right & $-5[15]$ & $35[5]$ \\
\hline 15 & Female & $28[28]$ & Otosclerosis & 5 & Left & $10[-5]$ & $45[0]$ \\
\hline & Median & $48[45]$ & & 7 & & $5[5]$ & $40[5]$ \\
\hline
\end{tabular}



Table 2. Participant pure tone audiogram thresholds (dB HL). Data for the control group are in brackets.

\begin{tabular}{|c|c|c|c|c|c|c|c|c|c|c|c|c|c|c|c|c|c|c|c|c|}
\hline \multirow[b]{3}{*}{$\begin{array}{l}\text { Participant } \\
\text { No. }\end{array}$} & \multicolumn{12}{|c|}{ Air Conduction } & \multicolumn{8}{|c|}{ Bone Conduction } \\
\hline & \multicolumn{6}{|c|}{ Test Ear Frequency (kHz) } & \multicolumn{6}{|c|}{ Non-test Ear Frequency (kHz) } & \multicolumn{4}{|c|}{$\begin{array}{l}\text { Test Ear Frequency } \\
(\mathrm{kHz})\end{array}$} & \multicolumn{4}{|c|}{$\begin{array}{c}\text { Non-test Ear } \\
\text { Frequency }(\mathbf{k H z})\end{array}$} \\
\hline & 0.25 & 0.5 & 1 & 2 & 4 & 8 & 0.25 & 0.5 & 1 & 2 & 4 & 8 & 0.5 & 1 & 2 & 4 & 0.5 & 1 & 2 & 4 \\
\hline 1 & $\begin{array}{l}25 \\
{[5]}\end{array}$ & $\begin{array}{l}35 \\
{[5]}\end{array}$ & $\begin{array}{l}35 \\
{[5]}\end{array}$ & $\begin{array}{l}25 \\
{[-10]}\end{array}$ & $\begin{array}{l}25 \\
{[5]}\end{array}$ & $\begin{array}{l}50 \\
{[0]}\end{array}$ & $\begin{array}{l}10 \\
{[5]}\end{array}$ & $\begin{array}{l}0 \\
{[5]}\end{array}$ & $\begin{array}{l}5 \\
{[0]}\end{array}$ & $\begin{array}{l}5 \\
{[5]}\end{array}$ & $\begin{array}{l}5 \\
{[-5]}\end{array}$ & $\begin{array}{l}15 \\
{[0]}\end{array}$ & -5 & $\begin{array}{l}-5 \\
{[-5]}\end{array}$ & 5 & 10 & -10 & -5 & 5 & 0 \\
\hline 2 & $\begin{array}{l}50 \\
{[0]}\end{array}$ & $\begin{array}{l}55 \\
{[5]}\end{array}$ & $\begin{array}{l}40 \\
{[5]}\end{array}$ & $\begin{array}{l}40 \\
{[5]}\end{array}$ & $\begin{array}{l}50 \\
{[0]}\end{array}$ & $\begin{array}{l}50 \\
{[10]}\end{array}$ & $\begin{array}{l}10 \\
{[-5]}\end{array}$ & $\begin{array}{l}10 \\
{[0]}\end{array}$ & $\begin{array}{l}5 \\
{[0]}\end{array}$ & $\begin{array}{l}25 \\
{[5]}\end{array}$ & $\begin{array}{l}20 \\
{[5]}\end{array}$ & $\begin{array}{l}30 \\
{[5]}\end{array}$ & 5 & $\begin{array}{l}10 \\
{[5]}\end{array}$ & 30 & 20 & 5 & 5 & 25 & 20 \\
\hline 3 & $\begin{array}{l}40 \\
{[5]}\end{array}$ & $\begin{array}{l}50 \\
{[10]}\end{array}$ & $\begin{array}{l}60 \\
{[5]}\end{array}$ & $\begin{array}{l}55 \\
{[10]}\end{array}$ & $\begin{array}{l}45 \\
{[15]}\end{array}$ & $\begin{array}{l}65 \\
{[10]}\end{array}$ & $\begin{array}{l}5 \\
{[10]}\end{array}$ & $\begin{array}{l}15 \\
{[0]}\end{array}$ & $\begin{array}{l}15 \\
{[0]}\end{array}$ & $\begin{array}{l}5 \\
{[0]}\end{array}$ & $\begin{array}{l}25 \\
{[10]}\end{array}$ & $\begin{array}{l}20 \\
{[10]}\end{array}$ & 20 & $\begin{array}{l}20 \\
{[0]}\end{array}$ & 25 & 15 & 15 & 10 & 25 & 15 \\
\hline 4 & $\begin{array}{l}60 \\
{[5]}\end{array}$ & $\begin{array}{l}55 \\
{[5]}\end{array}$ & $\begin{array}{l}30 \\
{[0]}\end{array}$ & $\begin{array}{l}25 \\
{[10]}\end{array}$ & $\begin{array}{l}30 \\
{[10]}\end{array}$ & $\begin{array}{l}30 \\
{[5]}\end{array}$ & $\begin{array}{l}10 \\
{[10]}\end{array}$ & $\begin{array}{l}15 \\
{[5]}\end{array}$ & $\begin{array}{l}10 \\
{[10]}\end{array}$ & $\begin{array}{l}15 \\
{[10]}\end{array}$ & $\begin{array}{l}0 \\
{[10]}\end{array}$ & $\begin{array}{l}20 \\
{[10]}\end{array}$ & 10 & $\begin{array}{l}5 \\
{[0]}\end{array}$ & 10 & 15 & 0 & 5 & 5 & 5 \\
\hline 5 & $\begin{array}{l}25 \\
{[15]}\end{array}$ & $\begin{array}{l}35 \\
{[10]}\end{array}$ & $\begin{array}{l}35 \\
{[10]}\end{array}$ & $\begin{array}{l}25 \\
{[15]}\end{array}$ & $\begin{array}{l}30 \\
{[15]}\end{array}$ & $\begin{array}{l}45 \\
{[35]}\end{array}$ & $\begin{array}{l}-5 \\
{[20]}\end{array}$ & $\begin{array}{l}10 \\
{[15]}\end{array}$ & $\begin{array}{l}10 \\
{[15]}\end{array}$ & $\begin{array}{l}5 \\
{[10]}\end{array}$ & $\begin{array}{l}15 \\
{[5]}\end{array}$ & $\begin{array}{l}10 \\
{[55]}\end{array}$ & 5 & $\begin{array}{l}0 \\
{[10]}\end{array}$ & 15 & 10 & 0 & -5 & 10 & 10 \\
\hline 6 & $\begin{array}{l}20 \\
{[-5]}\end{array}$ & $\begin{array}{l}30 \\
{[-5]}\end{array}$ & $\begin{array}{l}40 \\
{[-5]}\end{array}$ & $\begin{array}{l}30 \\
{[-5]}\end{array}$ & \begin{tabular}{|l}
50 \\
{$[-5]$}
\end{tabular} & \begin{tabular}{|l|}
80 \\
{$[10]$}
\end{tabular} & $\begin{array}{l}10 \\
{[-5]}\end{array}$ & $\begin{array}{l}20 \\
{[0]}\end{array}$ & \begin{tabular}{|l}
20 \\
{$[0]$}
\end{tabular} & $\begin{array}{l}20 \\
{[-10]}\end{array}$ & $\begin{array}{l}15 \\
{[10]}\end{array}$ & $\begin{array}{l}20 \\
{[0]}\end{array}$ & 10 & $\begin{array}{l}10 \\
{[-5]}\end{array}$ & 25 & 25 & 10 & 10 & 20 & 15 \\
\hline 7 & $\begin{array}{l}5 \\
{[10]}\end{array}$ & $\begin{array}{l}20 \\
{[15]}\end{array}$ & $\begin{array}{l}30 \\
{[10]}\end{array}$ & $\begin{array}{l}30 \\
{[10]}\end{array}$ & $\begin{array}{l}50 \\
{[15]}\end{array}$ & \begin{tabular}{|l}
15 \\
{$[15]$}
\end{tabular} & $\begin{array}{l}0 \\
{[10]}\end{array}$ & $\begin{array}{l}10 \\
{[10]}\end{array}$ & $\begin{array}{l}10 \\
{[10]}\end{array}$ & $\begin{array}{l}5 \\
{[15]}\end{array}$ & $\begin{array}{l}15 \\
{[10]}\end{array}$ & $\begin{array}{l}25 \\
{[5]}\end{array}$ & 5 & $\begin{array}{l}-10 \\
{[10]}\end{array}$ & 15 & 0 & 5 & -10 & 5 & -5 \\
\hline 8 & $\begin{array}{l}60 \\
{[-5]}\end{array}$ & $\begin{array}{l}50 \\
{[0]}\end{array}$ & $\begin{array}{l}40 \\
{[-5]}\end{array}$ & $\begin{array}{l}25 \\
{[-5]}\end{array}$ & $\begin{array}{l}25 \\
{[0]}\end{array}$ & $\begin{array}{l}25 \\
{[5]}\end{array}$ & $\begin{array}{l}0 \\
{[-5]}\end{array}$ & $\begin{array}{l}0 \\
{[-5]}\end{array}$ & \begin{tabular}{|l}
-5 \\
{$[-5]$}
\end{tabular} & $\begin{array}{l}-10 \\
{[-10]}\end{array}$ & $\begin{array}{l}-10 \\
{[-10]}\end{array}$ & $\begin{array}{l}0 \\
{[0]}\end{array}$ & -5 & $\begin{array}{l}5 \\
{[5]}\end{array}$ & 10 & -10 & -5 & -5 & 20 & -10 \\
\hline 9 & $\begin{array}{l}55 \\
{[10]}\end{array}$ & $\begin{array}{l}55 \\
{[5]}\end{array}$ & $\begin{array}{l}60 \\
{[10]}\end{array}$ & $\begin{array}{l}45 \\
{[20]}\end{array}$ & $\begin{array}{l}60 \\
{[15]}\end{array}$ & $\begin{array}{l}45 \\
{[5]}\end{array}$ & $\begin{array}{l}10 \\
{[5]}\end{array}$ & $\begin{array}{l}10 \\
{[5]}\end{array}$ & \begin{tabular}{|l}
5 \\
{$[10]$}
\end{tabular} & $\begin{array}{l}-5 \\
{[20]}\end{array}$ & $\begin{array}{l}15 \\
{[25]}\end{array}$ & $\begin{array}{l}0 \\
{[10]}\end{array}$ & 10 & $\begin{array}{l}10 \\
{[10]}\end{array}$ & 10 & 0 & 0 & 0 & 5 & 0 \\
\hline 10 & $\begin{array}{l}55 \\
{[5]}\end{array}$ & $\begin{array}{l}65 \\
{[5]}\end{array}$ & $\begin{array}{l}60 \\
{[0]}\end{array}$ & $\begin{array}{l}65 \\
{[-5]}\end{array}$ & \begin{tabular}{|l|}
65 \\
{$[-5]$}
\end{tabular} & \begin{tabular}{|l|}
50 \\
{$[-5]$}
\end{tabular} & $\begin{array}{l}5 \\
{[5]}\end{array}$ & $\begin{array}{l}5 \\
{[5]}\end{array}$ & \begin{tabular}{|l}
5 \\
{$[0]$}
\end{tabular} & $\begin{array}{l}15 \\
{[-5]}\end{array}$ & $\begin{array}{l}20 \\
{[-5]}\end{array}$ & $\begin{array}{l}10 \\
{[0]}\end{array}$ & 0 & \begin{tabular}{|l}
5 \\
{$[0]$}
\end{tabular} & 15 & 5 & 0 & 5 & 15 & 5 \\
\hline 11 & $\begin{array}{l}55 \\
{[10]}\end{array}$ & $\begin{array}{l}50 \\
{[0]}\end{array}$ & $\begin{array}{l}40 \\
{[5]}\end{array}$ & $\begin{array}{l}40 \\
{[0]}\end{array}$ & $\begin{array}{l}40 \\
{[15]}\end{array}$ & $\begin{array}{l}50 \\
{[5]}\end{array}$ & $\begin{array}{l}10 \\
{[5]}\end{array}$ & $\begin{array}{l}15 \\
{[0]}\end{array}$ & $\begin{array}{l}10 \\
{[0]}\end{array}$ & \begin{tabular}{|l}
5 \\
{$[0]$}
\end{tabular} & {$\left[\begin{array}{l}0 \\
{[20]}\end{array}\right.$} & \begin{tabular}{|l}
0 \\
{$[5]$}
\end{tabular} & 15 & \begin{tabular}{|l}
5 \\
{$[5]$}
\end{tabular} & 25 & 5 & 15 & 0 & 25 & 5 \\
\hline 12 & $\begin{array}{l}60 \\
{[5]}\end{array}$ & $\begin{array}{l}65 \\
{[10]}\end{array}$ & $\begin{array}{l}65 \\
{[5]}\end{array}$ & $\begin{array}{l}60 \\
{[10]}\end{array}$ & $\begin{array}{l}30 \\
{[5]}\end{array}$ & $\begin{array}{l}25 \\
{[5]}\end{array}$ & $\begin{array}{l}10 \\
{[5]}\end{array}$ & \begin{tabular}{|l}
20 \\
{$[10]$}
\end{tabular} & \begin{tabular}{|l}
5 \\
{$[5]$}
\end{tabular} & $\begin{array}{l}10 \\
{[5]}\end{array}$ & $\begin{array}{l}0 \\
{[5]}\end{array}$ & $\begin{array}{l}45 \\
{[0]}\end{array}$ & 15 & \begin{tabular}{|l|}
20 \\
{$[5]$}
\end{tabular} & 25 & 10 & 5 & 10 & 20 & 5 \\
\hline 13 & $\begin{array}{l}65 \\
{[5]}\end{array}$ & $\begin{array}{l}65 \\
{[5]}\end{array}$ & $\begin{array}{l}35 \\
{[5]}\end{array}$ & $\begin{array}{l}30 \\
{[5]}\end{array}$ & $\begin{array}{l}40 \\
{[0]}\end{array}$ & $\begin{array}{l}35 \\
{[0]}\end{array}$ & $\begin{array}{l}5 \\
{[5]}\end{array}$ & $\begin{array}{l}10 \\
{[5]}\end{array}$ & \begin{tabular}{|l}
5 \\
{$[5]$}
\end{tabular} & $\begin{array}{l}5 \\
{[5]}\end{array}$ & $\begin{array}{l}15 \\
{[0]}\end{array}$ & $\begin{array}{l}20 \\
{[10]}\end{array}$ & 5 & $\begin{array}{l}5 \\
{[5]}\end{array}$ & 15 & 15 & 5 & 5 & 5 & 15 \\
\hline 14 & $\begin{array}{l}40 \\
{[0]}\end{array}$ & $\begin{array}{l}40 \\
{[5]}\end{array}$ & $\begin{array}{l}35 \\
{[15]}\end{array}$ & $\begin{array}{l}30 \\
{[15]}\end{array}$ & \begin{tabular}{|l}
50 \\
{$[-5]$}
\end{tabular} & \begin{tabular}{|l}
40 \\
{$[60]$}
\end{tabular} & \begin{tabular}{|l}
5 \\
{$[0]$}
\end{tabular} & $\begin{array}{l}5 \\
{[5]}\end{array}$ & \begin{tabular}{|l|}
5 \\
{$[10]$}
\end{tabular} & $\begin{array}{l}5 \\
{[10]}\end{array}$ & $\begin{array}{l}15 \\
{[20]}\end{array}$ & \begin{tabular}{|l}
5 \\
{$[70]$}
\end{tabular} & 5 & $\begin{array}{l}-5 \\
{[15]}\end{array}$ & 10 & 15 & -5 & -5 & 0 & 15 \\
\hline 15 & $\begin{array}{l}70 \\
{[0]}\end{array}$ & \begin{tabular}{|l}
55 \\
{$[-5]$}
\end{tabular} & $\begin{array}{l}45 \\
{[5]}\end{array}$ & \begin{tabular}{|l}
50 \\
{$[-5]$}
\end{tabular} & $\begin{array}{l}20 \\
{[0]}\end{array}$ & \begin{tabular}{|l}
25 \\
{$[10]$}
\end{tabular} & $\begin{array}{l}10 \\
{[0]}\end{array}$ & \begin{tabular}{|l}
5 \\
{$[5]$}
\end{tabular} & $\begin{array}{l}10 \\
{[0]}\end{array}$ & \begin{tabular}{|l}
5 \\
{$[5]$}
\end{tabular} & \begin{tabular}{|l}
0 \\
{$[15]$}
\end{tabular} & $\begin{array}{l}0 \\
{[10]}\end{array}$ & 10 & $\begin{array}{l}10 \\
{[-5]}\end{array}$ & 20 & -5 & 5 & 10 & 5 & -5 \\
\hline
\end{tabular}


Table 3. Statistical analysis of peak-to-trough amplitudes $(\mu \mathrm{V})$ of P1-N1 and N1-P2 components of the CAEP on stimulation of the impaired ear of adults with unilateral conductive hearing impairment when compared with a control group of adults with normal hearing, with mean \pm 1 standard deviation displayed.

\begin{tabular}{llll}
\hline & & P1-N1 & N1-P2 \\
\hline $\begin{array}{l}\text { Mean Amplitude } \\
\mu \mathrm{V})\end{array}$ & $\begin{array}{l}\text { Hearing } \\
\text { Impaired } \\
\text { Control }\end{array}$ & $3.6 \pm 1.31$ & $5.5 \pm 1.88$ \\
& & $4.9 \pm 0.77$ & $2.9 \pm 1.54$ \\
$\mathrm{t}(28)$ & & 4.24 \\
$\mathrm{p}$ value & & $<0.001$ & $<0.001$ \\
\hline
\end{tabular}

Table 4. Statistical analysis of absolute peak latencies (ms) of P1, N1 and P2 components of the CAEP on stimulation of the impaired ear of adults with unilateral conductive hearing impairment when compared with a control group of adults with normal hearing, with mean \pm 1 standard deviation displayed.

\begin{tabular}{|c|c|c|c|c|}
\hline & & P1 & N1 & P2 \\
\hline \multirow[t]{2}{*}{$\begin{array}{l}\text { Mean Peak } \\
\text { Latency (ms) }\end{array}$} & $\begin{array}{l}\text { Hearing } \\
\text { Impaired }\end{array}$ & $56.4 \pm 12.58$ & $109.9 \pm 9.99$ & $178.0 \pm 14.71$ \\
\hline & Control & $69.5 \pm 17.66$ & $120.6 \pm 21.74$ & $191.3 \pm 32.26$ \\
\hline $\mathrm{t}(28)$ & & 2.36 & 1.70 & 1.45 \\
\hline $\mathrm{p}$ value & & 0.03 & 0.09 & 0.16 \\
\hline
\end{tabular}




\section{Figure Legends}

Figure 1. Mean pure tone audiogram for both groups. Air conduction thresholds for the hearing impaired group are represented by the dashed black line, with masked bone conduction thresholds represented by the solid black line. Air conduction thresholds for the normal hearing group are represented by the grey line.

Figure 2. Grand average CAEP waveform for both groups $(n=14)$. The solid line represents the hearing impaired group data and the dashed line represents the control group data. 1 participant per group was omitted due to inability to retrieve data from the data collection site.

Figure 3. Grand average of residual noise for both groups $(n=14)$. The solid line represents the hearing impaired group data and the dashed line represents the control group data. 1 participant per group was omitted due to inability to retrieve data from the data collection site.

Figure 4. Peak-to-trough amplitudes $(\mu \mathrm{V})$ of P1-N1 and N1-P2 components of the CAEP on stimulation of the impaired ear of adults with unilateral conductive hearing impairment ( $n=15$; white boxes) and a control group of adults with normal hearing ( $n=15$; shaded boxes). Outliers are represented by a circle.

Figure 5. Absolute peak latencies (ms) of P1, N1 and P2 components of the CAEP on stimulation of the impaired ear of adults with unilateral conductive hearing impairment $(\mathrm{n}=15$; white boxes) and a control group of adults with normal hearing ( $\mathrm{n}=15$; shaded boxes). Outliers are represented by a circle and extreme outliers are represented by a star. 
Figures

Figure 1

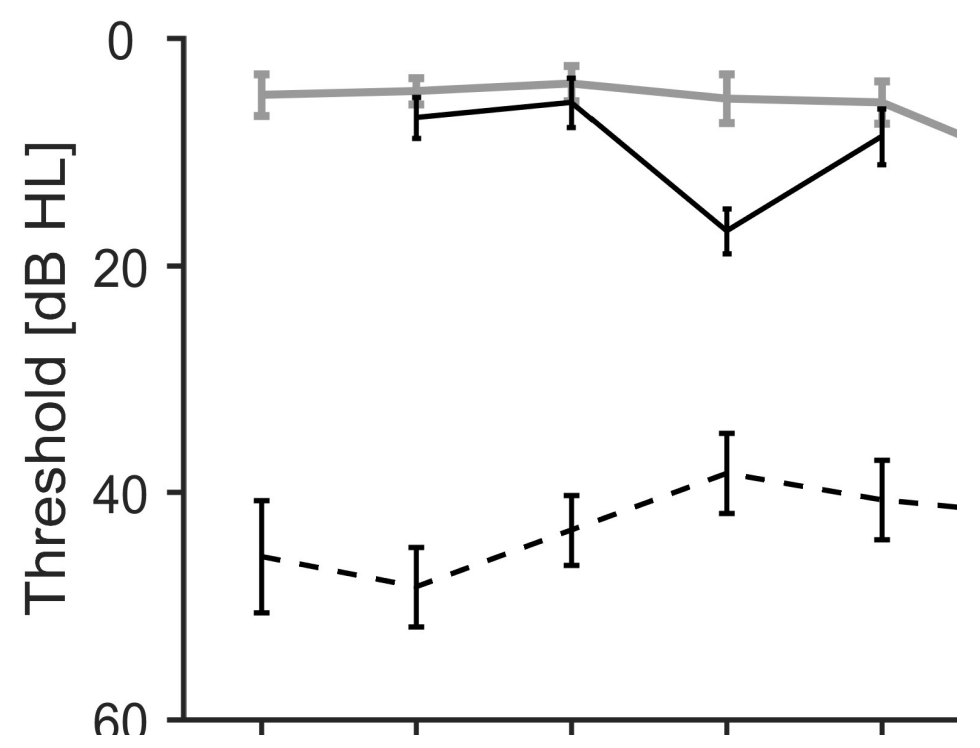


Figure 2

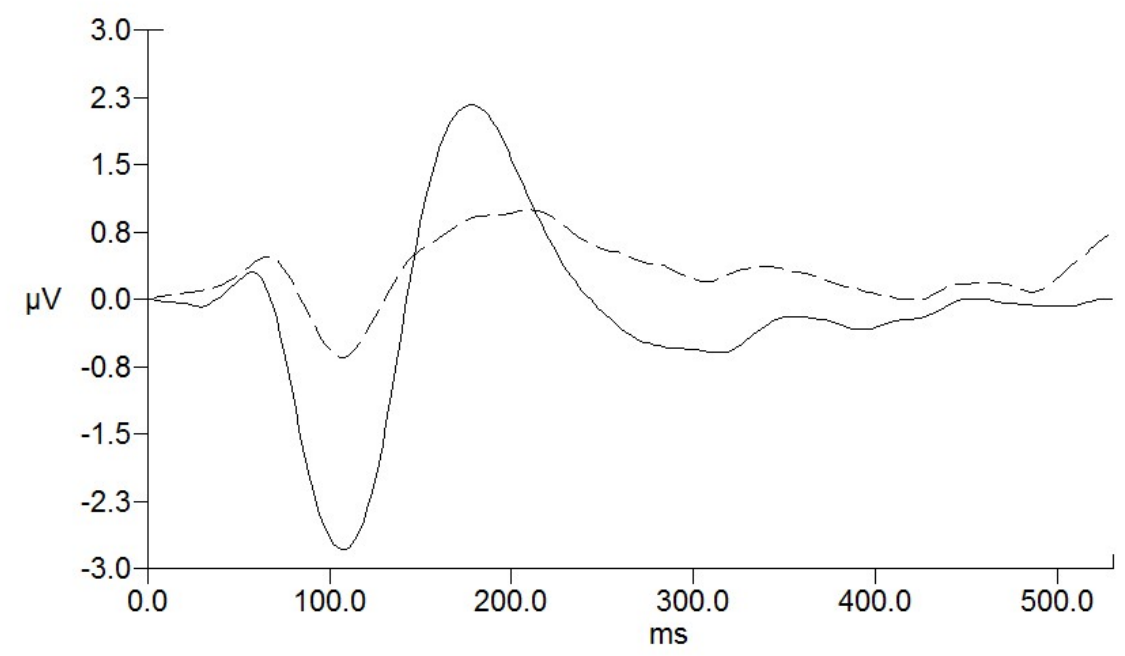


Figure 3

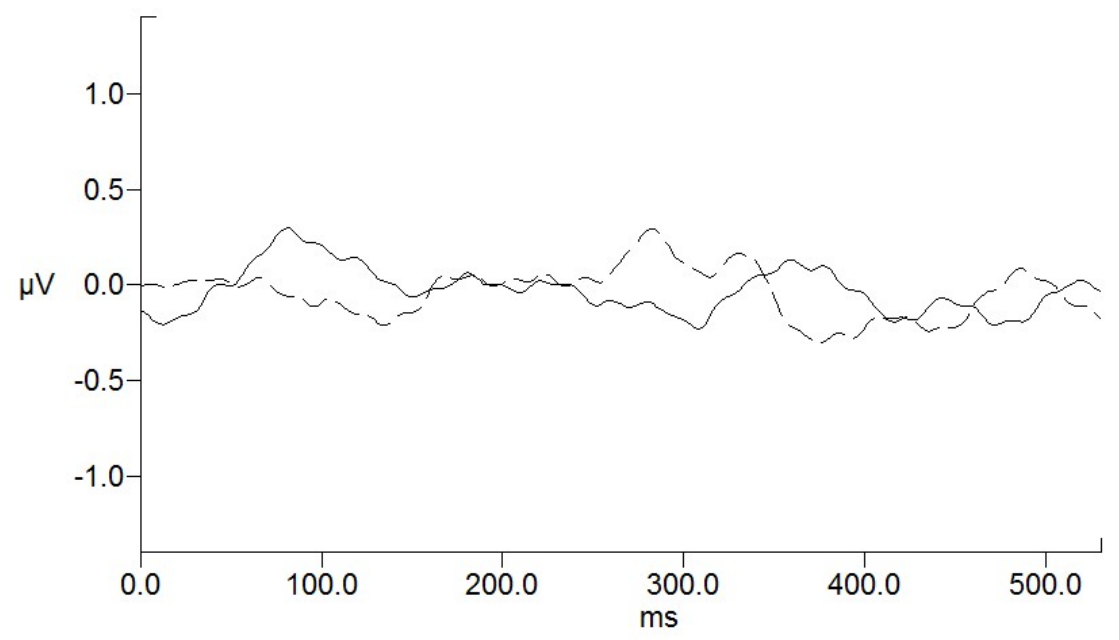


Figure 4

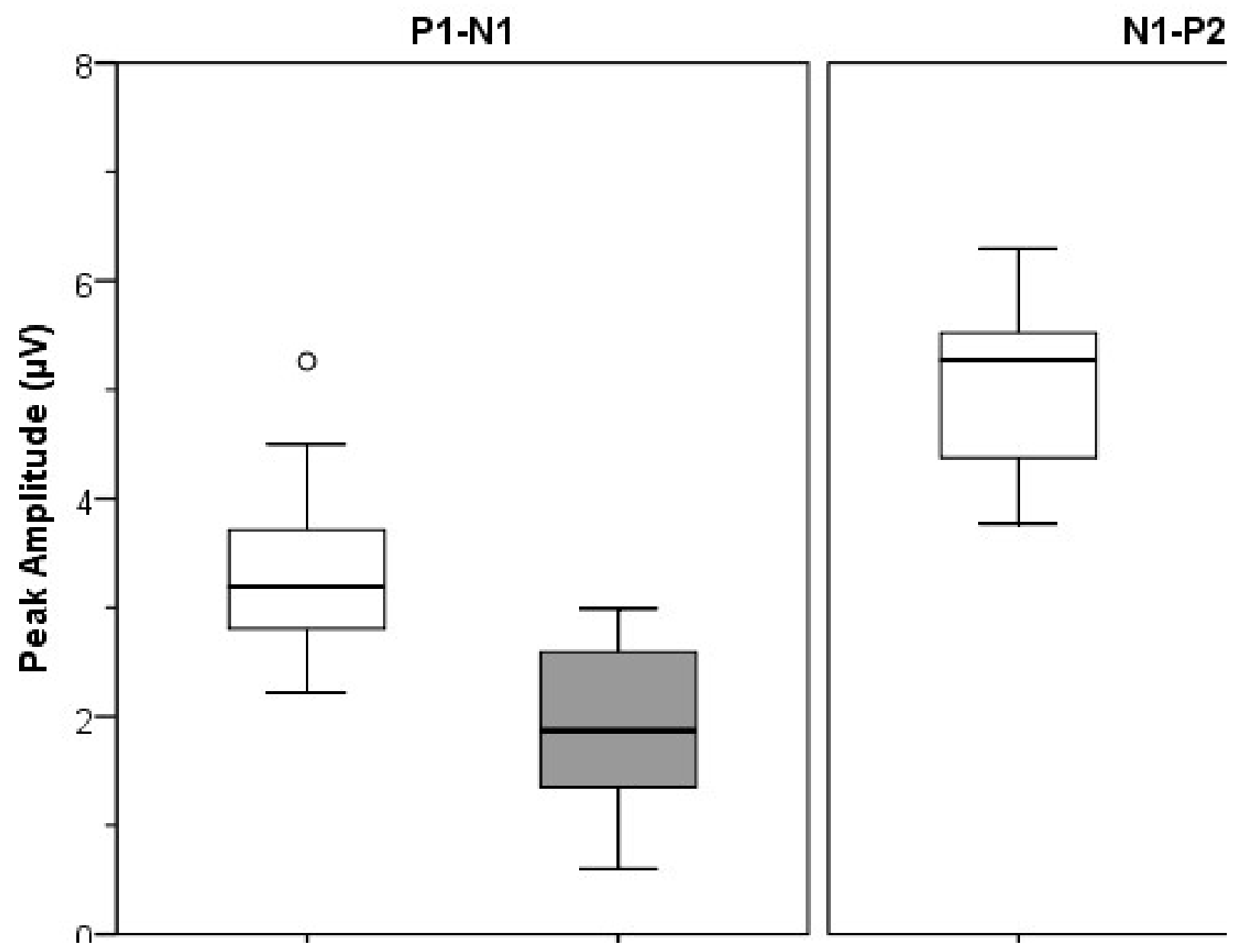


Figure 5
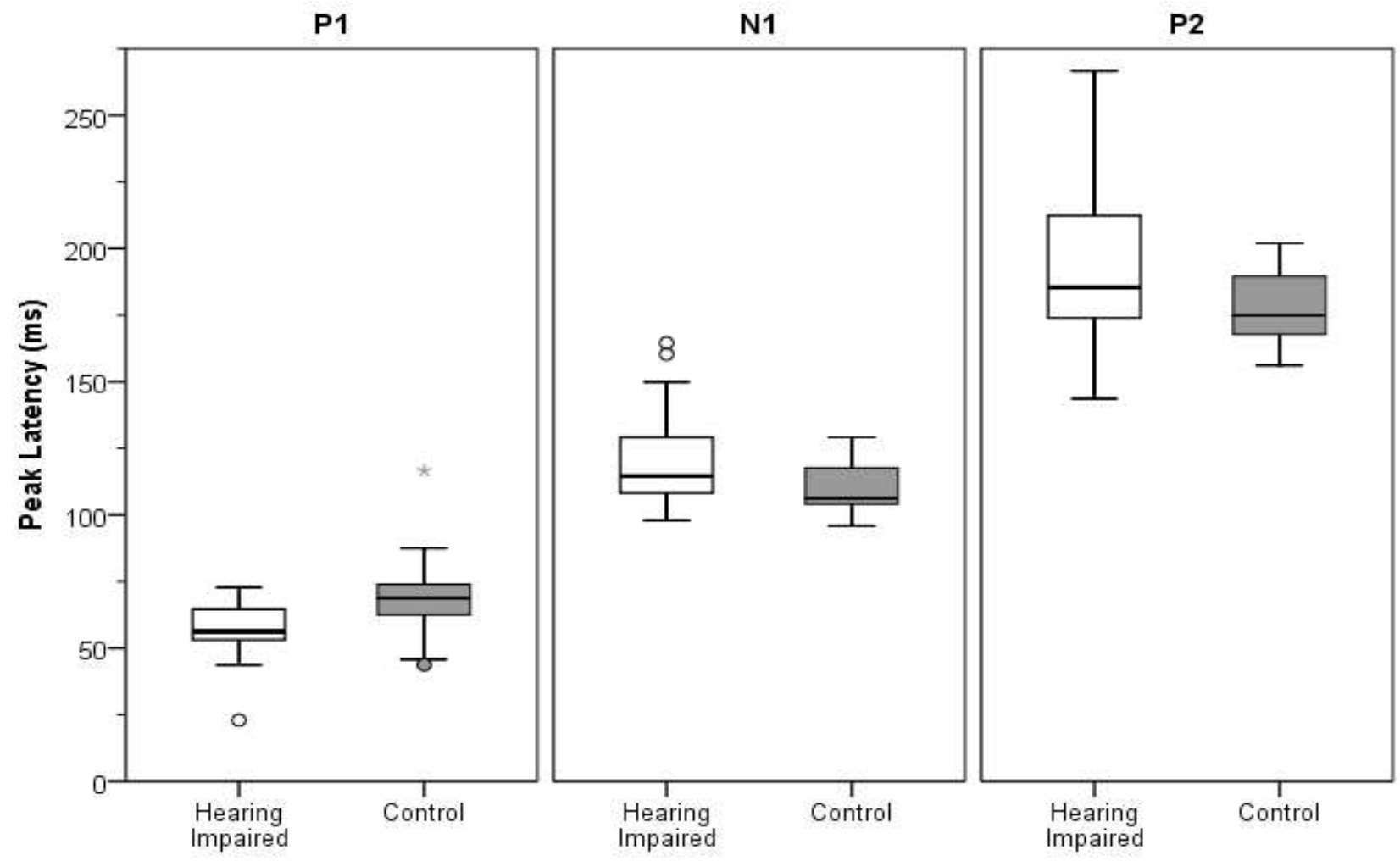

Subject Group 